\title{
KARAKTER MORFOLOGI BEBERAPA GALUR KACANG TANAH F4 (Arachis hypogaea L.) TERHADAP CEKAMAN NAUNGAN
}

\section{THE MORPHOLOGICAL CHARACTERS OF SEVERAL F4 PEANUT (Arachis hypogaea L.) LINES SHADE STRESS}

\author{
Rica Lifiani. ${ }^{1)}$, I Wayan Sutresna ${ }^{2)}$, A. Farid Hemon ${ }^{3)}$ \\ ${ }^{1,2,3}$ Program Studi Agroekoteknologi, Universitas Mataram, Kota Mataram, Indonesia. \\ *Email Penulis Korespondensi: ricalifiani123@gmail.com
}

\begin{abstract}
ABSTRAK
Penelitian ini bertujuan untuk mengetahui karakter morfologi beberapa galur kacang tanah F4 terhadap cekaman naungan. Penelitian ini menggunakan Rancangan Acak Lengkap petak terbagi. Petak utama: perlakuan tanpa naungan $\left(\mathrm{n}_{0}\right)$ dan perlakuan cekaman naungan $\left(\mathrm{n}_{1}\right)$ dengan menggunakan paranet $65 \%$. Anak petak: 15 galur kacang tanah generasi F-4 (BISON, G 200-I, G 300-II, G1-UI, G3T4, TAKAR, G2T1, G7-UIII, G2T3, G3T7, G3T10, DOMBA, G2D2, G3D3, G3D8). Kombinasi perlakuan diulang sebanyak 3 kali. Hasil penelitian menunjukan bahwa galur kacang tanah berinteraksi secara nyata pada karakter morfologi jumlah cabang. Beberapa galur kacang tanah generasi F4 menunjukan karakter morfologi yang berbeda seperti tinggi tanaman, jumlah cabang, umur berbunga, jumlah bunga, dan berat berangkasan segar tanaman. cekaman naungan semuanya menghasilkan karakter morfologi yang berbeda kecuali jumlah kerapatan trichoma dan jumlah polong cipo. Galur-galur kacang tanah yang memiliki sifat agak toleran terhadap cekaman naungan yaitu G3T4, G2T1, G3T7, G3T10, DOMBA, G3D3 dan G3D8.

Kata kunci: Naungan, Galur Kacang Tanah F4, Morfologi
\end{abstract}

\begin{abstract}
ABSTRACK
The objective of this research was to determine the morphological characters of several F4 peanut lines on shade stress. This research used a completely randomized design with a split-plot design. Main plot: treatment without shade $\left(\mathrm{n}_{0}\right)$ and shading stress treatment $\left(\mathrm{n}_{1}\right)$ using $65 \%$ paranet shade. Subplots: 15 peanut lines of F-4 generation (BISON, G 200-I, G 300-II, G1-UI, G3T4, TAKAR, G2T1, G7-UIII, G2T3, G3T7, G3T10, DOMBA, G2D2, G3D3, G3D8). The treatment combination was repeated 3 times. significant interactions with the morphological characters of the number of branches. Several peanut lines of the F4 generation showed different morphological characters such as plant height, number of branches, flowering age, number of flowers, and weight of plant fresh stems. Meanwhile, all of the shading stresses produced different morphological characters except for the number of trichoma density and the number of cipo pods. Peanut linesshowing tolerant to shade stress were G3T4, G2T1, G3T7, G3T10, DOMBA, G3D3, and G3D8.
\end{abstract}

Keywords: Shade, F4 peanut lines, Morphological

\section{PENDAHULUAN}

Kacang tanah (Arachis hypogaea L.) merupakan salah satu produk pertanian tanaman pangan yang bernilai ekonomi tinggi, karena dapat memenuhi kebutuhan gizi masyarakat terutama kebutuhan protein dan lemak nabati. Kacang tanah juga dapat dikonsumsi dalam berbagai bentuk, diantaranya sebagai bahan sayur, saus dan digoreng atau direbus, dan sebagai bahan industri dapat dibuat keju, mentega, sabun dan minyak. Selain itu, daun kacang tanah juga dapat dimanfaatkan untuk pakan ternak dan pupuk hijau (Suprapto, 2008).

Peningkatan produksi kacang tanah dapat dilakukan secara intensifikasi dan ekstensifikasi. Peningkatan ekstensifikasi merupakan perluasan lahan dengan cara memperoleh lahan-lahan baru yang bisa ditanami tanaman dan menghasilkan produksi tanaman yang dapat memenuhi kebutuhan pangan masyarakat (Ihsan, et al., 2016). Ekstensifikasi ini dapat juga dilakukan pada lahan marjinal seperti di lahan kering, dan lahan di bawah tegakan pohon. 
Penanaman kacang tanah di bawah tegakan pohon merupakan alternatif dalam meningkatkan pendapatan di lahan perkebunan. Namun penggunaan tanaman tahunan sebagai naungan secara umum kurang produktif bagi tanaman kacang tanah. Penanaman di bawah tegakan pohon cenderung mendapatkan intensitas cahaya yang lebih rendah. Cahaya matahari yang rendah menjadi pembatas terhadap pertumbuhan dan perkembangan kacang tanah (Hemon, et al., 2018).

Radiasi matahari yang sangat berpengaruh terhadap produksi bahan kering adalah kualitas sinar (panjang gelombang), intensitas sinar dan lama penyinaran (Ashari, 2006). Intensitas cahaya yang rendah pada saat pembentukan ginofor dapat mengurangi jumlah ginofor. Selain, itu rendahnya intensitas penyinaran pada masa pengisian polong menurunkan jumlah dan berat polong serta meningkatkan jumlah polong hampa (Adisarwanto. 2000).

Kekurangan cahaya akibat naungan menyebabkan perubahan terhadap morfofisiologi tanaman (Perrin et al., 2013). Tanaman kedelai yang memperoleh intensitas naungan $50 \%$ memiliki pertumbuhan tanaman yang paling rendah dibandingkan pada intensitas naungan $0 \%$ dan $25 \%$. Semakin tinggi intensitas naungan yang diterima tanaman menyebabkan pengurangan berat kering tanaman, laju asimilasi bersih, laju pertumbuhan tanaman, dan jumlah polong per rumpun (Handriawan et al., 2016). Rendahnya intensitas cahaya saat perkembangan tanaman dapat mengakibatkan timbulnya gejala etiolasi yang disebabkan oleh aktivitas hormon auksin.

Kegiatan karakterisasi sifat morfo-agro dapat memilih pertumbuhan tanaman yang ideal dengan sifat ketahanan/toleransi tanaman terhadap pengaruh abiotik atau biotik (Rais, 2004). Mekanisme ketahanan tanaman terhadap pengaruh abiotik tergantung pada kemampuan tanaman itu sendiri untuk menghindari atau mempertahankan diri dari kondisi yang kurang menguntungkan.

Hasil penelitian Hemon, et al., (2012-2016) telah menghasilkan galur mutan kacang tanah G200-I dan G300-II yang toleran terhadap kekeringan. Galur-galur mutan ini ingin ditambah sifat toleran terhadap naungan, sehingga galur mutan ini telah disilangkan dengan varietas-varietas nasional yang toleran naungan (Hemon et al., 2018-2019). Hasil hibridisasi tersebut telah menghasilkan galur-galur kacang tanah generasi F-4. Galur-galur ini belum diketahui karakter morfologi terutama pada cekaman naungan di bawah paranet. Oleh karena itu, penelitian ini bertujuan untuk mengetahui pengaruh cekaman naungan terhadap karakter morfologi beberapa galur kacang tanah generasi F-4.

\section{METODE PENELITIAN}

Penelitian ini telah dilakukan dari bulan Maret sampai bulan Juli 2020 di Rumah Kaca Universitas Mataram, Desa Nyiur Lembang, Kecematan Narmada, Kabupaten Lombok Barat. Penelitian ini dirancang menggunakan Rancangan Acak Lengkap Split plot design yang terdiri dari petak utama dan anak petak. Perlakuan petak utama terdiri dari perlakuan tanpa naungan $\left(\mathrm{n}_{0}\right)$ dan cekaman naungan $\left(\mathrm{n}_{1}\right)$. Sedangkan anak petak terdiri dari 15 galur kacang tanah generasi F-4 yaitu BISON, G 200-I, G 300-II, G1-UI, G3T4, TAKAR, G2T1, G7-UIII, G2T3, G3T7, G3T10, DOMBA, G2D2, G3D3, G3D8. Galur-galur kacang tanah F-4 tersebut ditanam pada kondisi tanpa naungan $\left(\mathrm{n}_{0}\right)$ dan ditanam pada kondisi cekaman naungan $\left(\mathrm{n}_{1}\right)$. Perlakuan diulang sebanyak 3 kali sehingga menghasilkan 90 kombinasi.

Pelaksanaan percobaan terdiri dari persiapan benih, persiapan media tanam, penanaman, perlakuan cekaman naungan, perawatan tanaman, dan pemanenan. Sebelum 
benih kacang tanah ditanam terlebih dahulu dipisahkan dan diseleksi. Penanaman kacang tanah dilakukan di polybag ukuran $40 \mathrm{~cm}$ x $40 \mathrm{~cm}$ yang telah diisi tanah $10 \mathrm{~kg}$. Masing-masing polybag ditanami tiga biji kacang tanah dan diberikan Furadan $3 \mathrm{G}$. Perlakuan cekaman naungan dilakukan sejak awal penanaman menggunakan paranet hitam dengan intensitas cahaya yang masuk maksimal 65\%. Perawatan tanaman terdiri dari penyiraman, pemupukan, penyiangan dan pembumbunan, dan pengendalian hama penyakit. Panen dilakukan pada umur 100 hari setelah tanam (hst) Pengamatan yang diamati pada penelitian ini yaitu: tinggi tanaman $(\mathrm{cm})$, panjang ruas batang $(\mathrm{cm})$, jumlah daun/tanaman (helai), jumlah cabang/tanaman, umur berbunga, jumlah bunga/tanaman, berat berangkasan segar tanaman/tanaman (g), berat berangkasan kering tanaman/tanaman $(\mathrm{g})$, berat berangkasan segar akar/tanaman $(\mathrm{g})$, berat berangkasan kering akar/tanaman (g), berat berangkasan segar polong/tanaman (g), berat berangkasan kering polong/tanaman $(\mathrm{g})$, jumlah kerapatan trichoma tiap bidang pandang $10 * 10$, luas daun $\left(\mathrm{cm}^{2}\right)$, jumlah polong/tanaman, jumlah polong isi/tanaman, jumlah polong cipo/tanaman. Data hasil pengamatan dianalisis menggunakan analisis keragaman (Analisis of Variance), pada taraf nyata 5\%. Perlakuan yang menunjukan berbeda nyata diuji lanjut dengan Uji Duncan Multiple Range Test (DMRT) dengan taraf nyata $5 \%$.

\section{HASIL DAN PEMBAHASAN}

Rangkuman anova pengaruh cekaman naungan pada berbagai fase pertumbuhan terhadap karakter morfologi tanaman kacang tanah ditampilakan pada Tabel 1.

Tabel 1. Rangkuman anova taraf 5\% pada berbagai fase pertumbuhan terhadap karakter morfologi tanaman kacang tanah

\begin{tabular}{|c|c|c|c|}
\hline Karakter morfologi & $\mathrm{N}$ & G & $\mathrm{N} * \mathrm{G}$ \\
\hline Tinggi tanaman $(\mathrm{cm})$ & $\mathrm{S}$ & $\mathrm{S}$ & NS \\
\hline Panjang ruas batang $(\mathrm{cm})$ & $\mathrm{S}$ & NS & NS \\
\hline Jumlah daun (helai) & $S$ & NS & NS \\
\hline Jumlah cabang & S & $\mathrm{S}$ & $\mathrm{S}$ \\
\hline Umur berbunga (hari) & $S$ & $S$ & NS \\
\hline Jumlah bunga & $S$ & S & NS \\
\hline Berat berangkasan segar tanaman $(\mathrm{g})$ & S & $\mathrm{S}$ & NS \\
\hline Berat berangkasan kering tanaman $(\mathrm{g})$ & $\mathrm{S}$ & NS & NS \\
\hline Berat berangkasan segar akar (g) & $\mathrm{S}$ & NS & NS \\
\hline Berat berangkasan kering akar (g) & $\mathrm{S}$ & NS & NS \\
\hline Berat berangkasan segar polong (g) & S & NS & NS \\
\hline Berat berangkasan kering polong $(\mathrm{g})$ & $\mathrm{S}$ & NS & NS \\
\hline Jumlah kerapatan trichoma tiap bidang pandang $10 * 10$ & NS & NS & NS \\
\hline Luas daun $\left(\mathrm{cm}^{2}\right)$ & $\mathrm{S}$ & NS & NS \\
\hline Jumlah polong & S & NS & NS \\
\hline Jumlah polong isi & $\mathrm{S}$ & NS & NS \\
\hline Jumlah polong cipo & NS & NS & NS \\
\hline
\end{tabular}

Keterangan: $\mathrm{N}=$ Naungan, $\mathrm{G}=$ Galur, $\mathrm{N}^{*} \mathrm{G}=$ Interaksi naungan dan galur, $\mathrm{S}=$ Signifikan, $\mathrm{NS}=$ Non si gnifikan

Penanaman kacang tanah di bawah tegakan pohon biasanya dilakukan secara tumpang sari dengan tanaman tahunan. Penanaman kacang tanah ini dilakukan di bawah naungan dengan menggunakan paranet hitam 65\% sebagai simulasi dengan penanaman di bawah

Lifiani, R., Sutresna., I.W., dan Hemon, A.F. 
tegakan pohon. Pertumbuhan tanaman kacang tanah di bawah naungan dapat berpengaruh terhadap pemanfaatan cahaya yang diperoleh tanaman kurang optimal. Proses pertumbuhan kacang tanah tidak terlepas dari berbagai macam faktor yang mempengaruhi salah satu faktor yang sangat berpengaruh adalah cahaya. Cahaya merupakan salah satu faktor lingkungan yang paling berpengaruh terhadap pertumbuhan tanaman terutama berkaitan dengan proses fotosintesis .

Berdasarkan Tabel 1. rangkuman hasil Anova taraf 5\% pada berbagai karakter morfologi kacang tanah bahwa terdapat pengaruh faktor naungan terhadap semua karakter morfologi kacang tanah kecuali jumlah kerapatan trikoma dan jumlah polong hampa. Sedangkan karakter morfologi yang dipengaruhi beberapa galur kacang tanah seperti tinggi tanaman, umur berbunga, jumlah bunga, dan berat berangkasan segar tanaman. Sedangkan naungan terdapat interaksi $\left(\mathrm{N}^{*} \mathrm{G}\right)$ dengan galur kacang tanah pada karakter morfologi jumlah cabang.

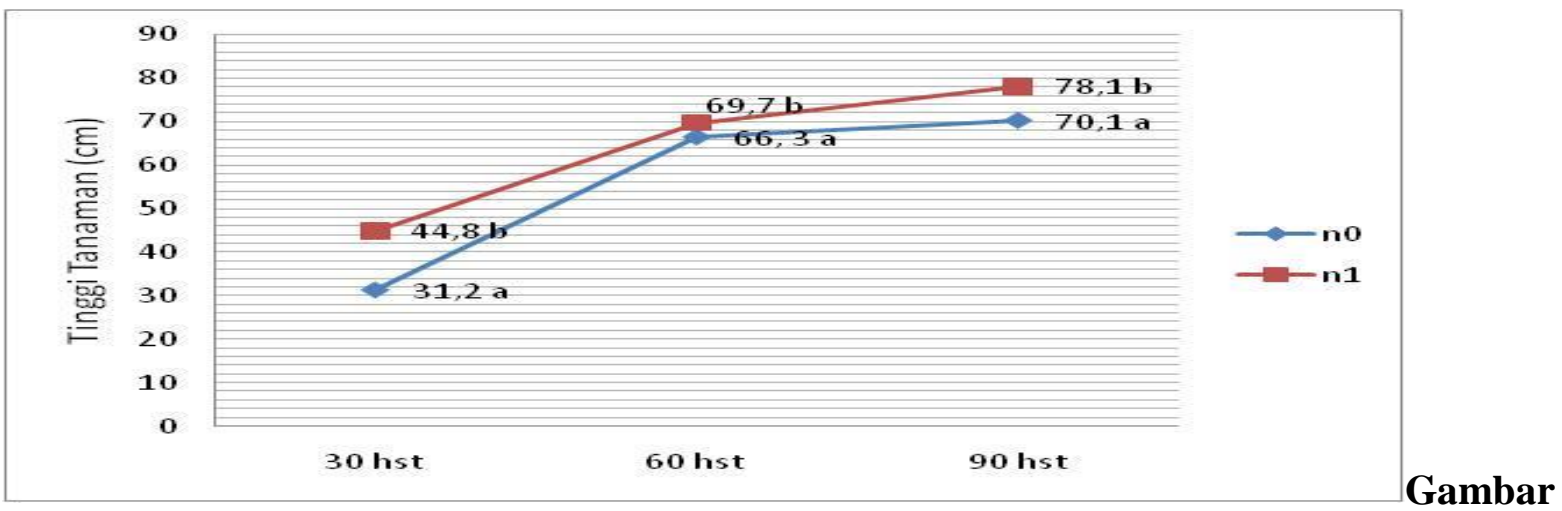

1. Pengaruh Cekaman Naungan terhadap Tinggi Tanaman Kacang Tanah $(\mathrm{cm})$

Keterangan: Angka-angka yang diikuti oleh huruf yang sama pada titik umur tanaman yang sama menunjukan hasil yang tidak berbeda nyata pada uji DMRT taraf nyata 5\%; $\mathrm{n}_{0=}$ tanpa naungan, $\mathrm{n}_{1=}$ cekaman naungan.

Gambar 1. menunjukan bahwa Perlakuan cekaman naungan memberikan pertumbuhan yang lebih tinggi dibandingkan dengan perlakuan tanpa naungan. Pertumbuhan tinggi tanaman kacang tanah pada cekaman naungan akibat adanya hormon auksin yang bekerja untuk pemanjangan sel, dimana hormon auksin tersebut akan bekerja aktif apabila intensitas cahaya rendah sehingga tanaman kacang tanah tersebut mengalami pertumbuhan etiolasi. Hal ini juga sesuai dengan pernyataan Maghfiroh (2017) bahwa tanaman yang memperoleh banyak cahaya dari lingkungan akan menyebabkan pertumbuhan tanaman tersebut akan terhambat karena cahaya dapat merusak kerja dari hormon pertumbuhan (auksin). 


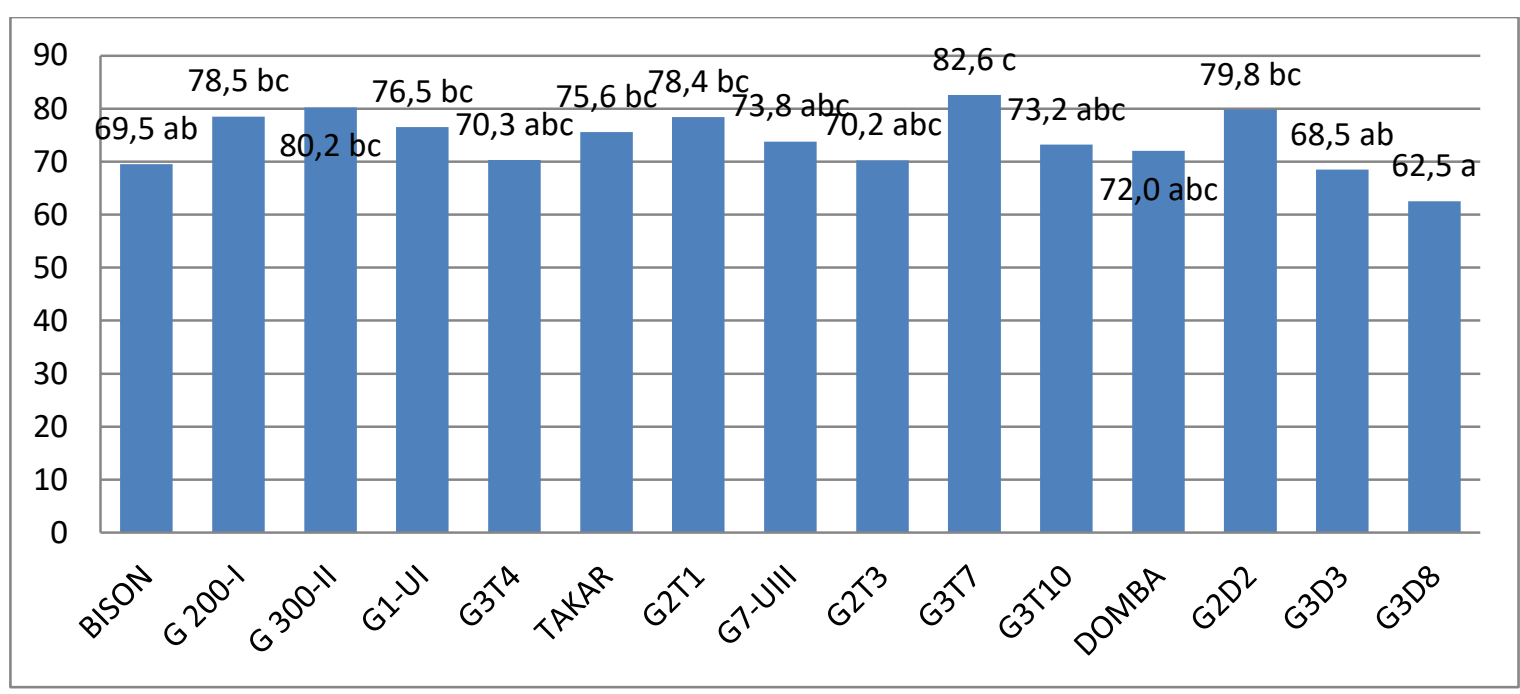

Gambar 2. Karakter Beberapa Galur pada Tinggi Tanaman (cm) Kacang Tanah terhadap Cekaman Naungan

Keterangan: Angka-angka yang diikuti oleh huruf yang sama pada titik umur tanaman yang sama menunjukan hasil yang tidak berbeda nyata pada uji DMRT taraf nyata 5\%; $\mathrm{n}_{0=}$ tanpa naungan, $\mathrm{n}_{1=}$ cekaman naungan

Sedangkan pada Gambar 2. bahwa perlakuan galur kacang tanah berpengaruh terhadap pertumbuhan tinggi tanaman kacang tanah. Perlakuan galur G3T7 menunjukan pertumbuhan yang lebih tinggi dibandingkan G3D8. Pertumbuhan tinggi tanaman kacang tanah pada galur tersebut merupakan upaya tanaman untuk memperoleh cahaya yang optimal.

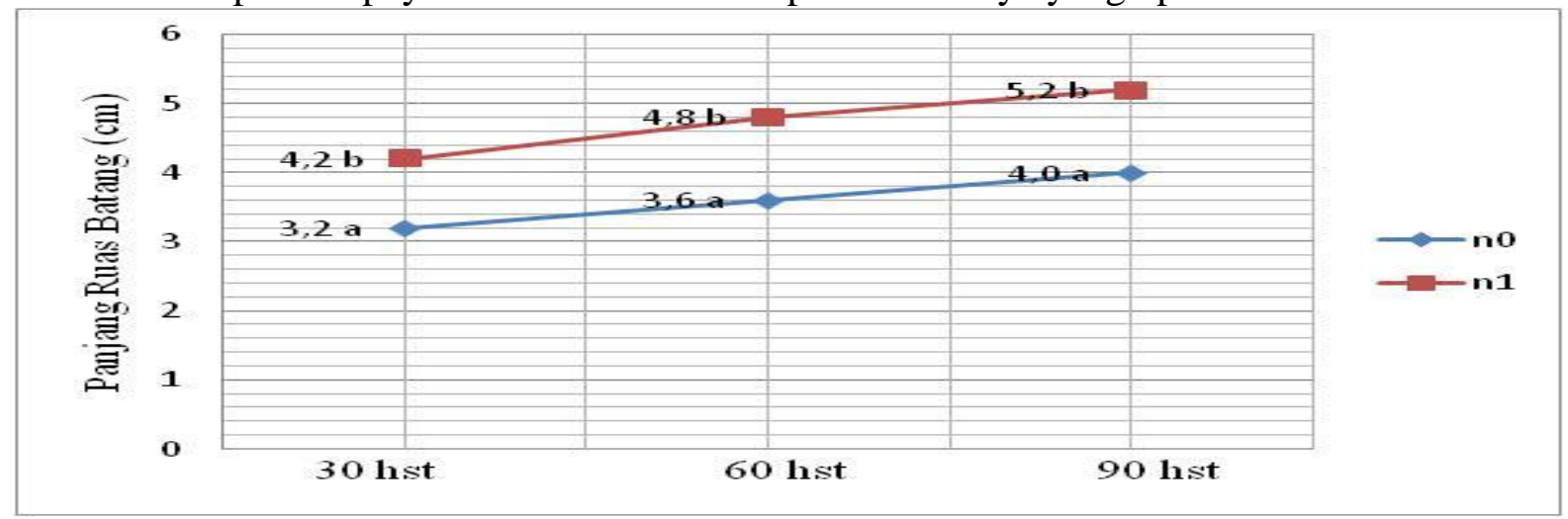

Gambar 3. Pengaruh Cekaman Naungan terhadap Panjang Ruas Batang (cm)

Keterangan: Angka-angka yang diikuti oleh huruf yang sama pada titik umur tanaman yang sama menunjukan hasil yang tidak berbeda nyata pada uji DMRT taraf nyata 5\%; $\mathrm{n}_{0=}$ tanpa naungan, $\mathrm{n}_{1=}$ cekaman naungan

Pada Gambar 3. menunjukan bahwa pengaruh naungan berbeda nyata terhadap karakter panjang ruas batang. Berdasarkan nilai rerata bahwa perlakuan cekaman naungan lebih tinggi dibandingkan dengan perlakuan tanpa naungan. Pertumbuhan panjang ruas batang kacang tanah berhubungan dengan pertumbuhan tinggi tanaman yang dipengaruhi oleh faktor lingkungan akibat intensitas cahaya rendah yaitu hormon auksin. Berdasarkan Gambar 4. pengaruh perlakuan galur kacang tanah tidak menunjukan berbeda nyata terhadap panjang ruas batang.

Lifiani, R., Sutresna., I.W., dan Hemon, A.F. 


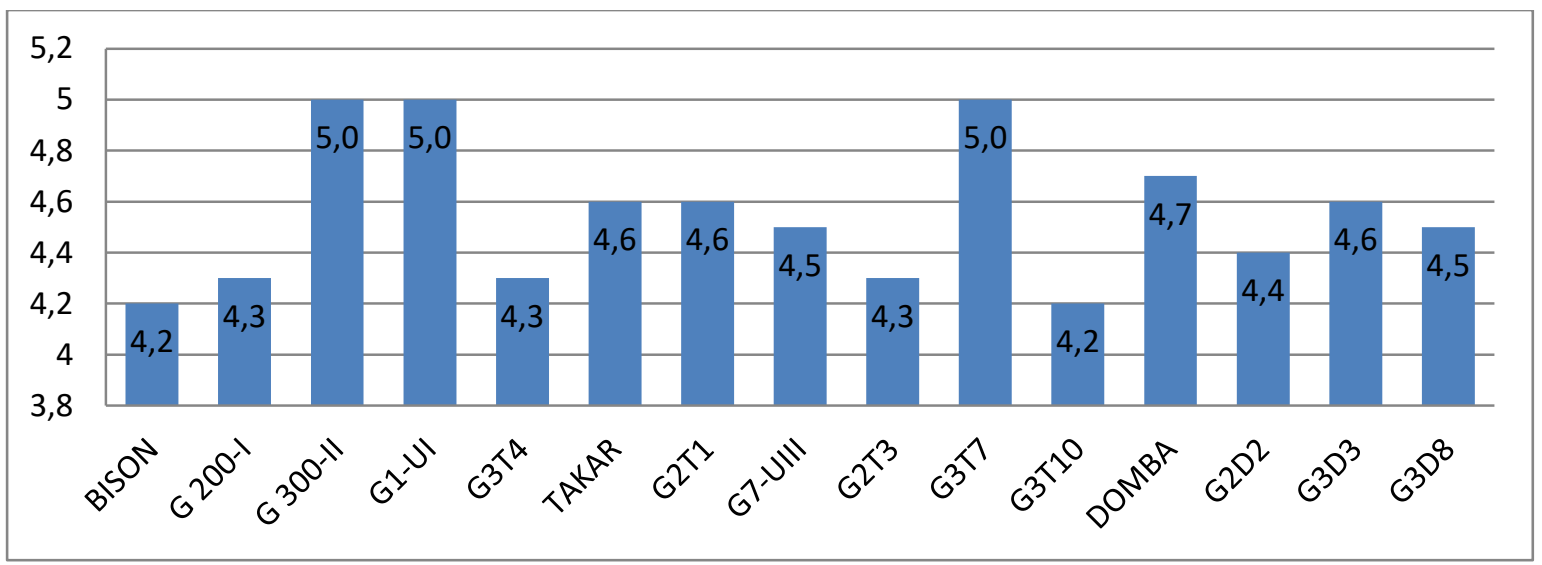

Gambar 4. Karakter Beberapa Galur pada Panjang Ruas Batang $(\mathrm{cm})$ Kacang Tanah terhadap Cekaman Naungan

Keterangan: Angka-angka yang diikuti oleh huruf yang sama pada titik umur tanaman yang sama menunjukan hasil yang tidak berbeda nyata pada uji DMRT taraf nyata 5\%; $\mathrm{n}_{0=}$ tanpa naungan, $\mathrm{n}_{1=}$ cekaman naungan.

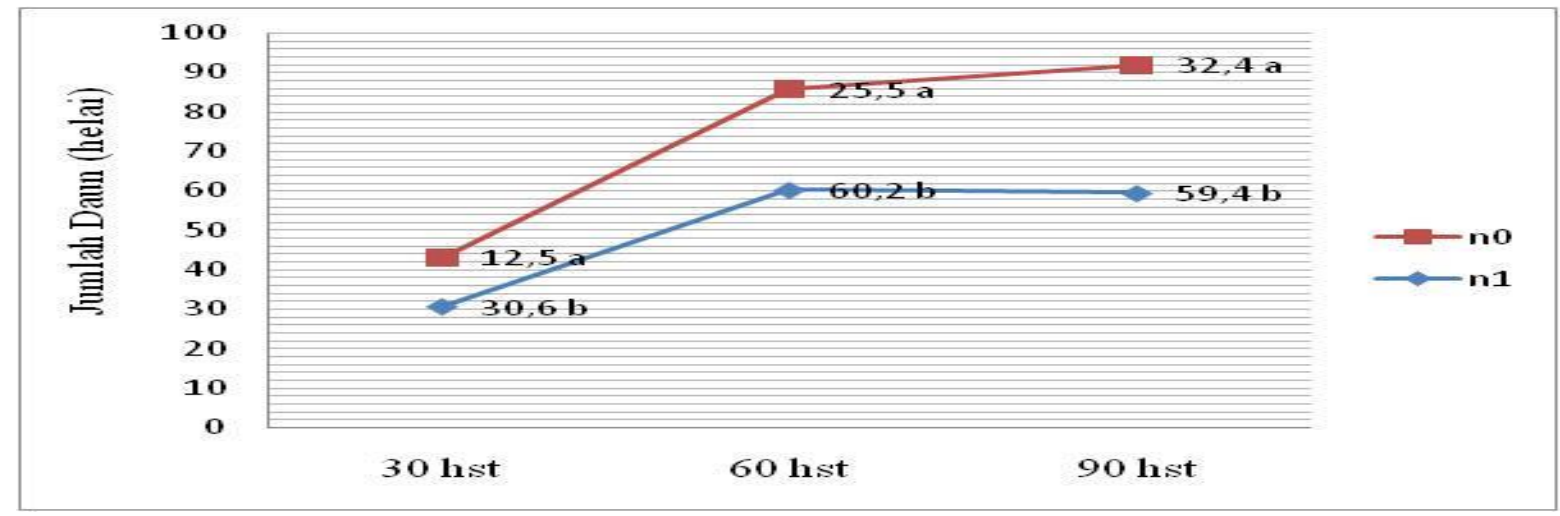

Gambar 5. Pengaruh Cekaman Naungan terhadap Jumlah Daun umur 30 hst, umur 60 hst, dan umur $90 \mathrm{hst}$

Keterangan: Angka-angka yang diikuti oleh huruf yang sama pada titik umur tanaman yang sama menunjukan hasil yang tidak berbeda nyata pada uji DMRT taraf nyata 5\%; $\mathrm{n}_{0=}$ tanpa naungan, $\mathrm{n}_{1=}$ cekaman naungan

Berdasarkan Gambar 5. bahwa jumlah daun perlakuan cekaman naungan menghasilkan jumlah daun yang lebih sedikit dibandingkan tanpa naungan. Perlakuan yang ternaungi pada tanaman kacang tanah dapat mengurangi jumlah daun untuk mengimbangi jumlah cahaya yang masuk terbatas. Jumlah daun pada perlakuan tanpa naungan lebih banyak dikarenakan proses fotosintesisnya lebih optimal. Hal serupa juga dilaporkan Anggraeni (2010) yang menyatakan bahwa pengaruh naungan menghasilkan jumlah daun yang lebih sedikit dibandingkan dengan tanaman yang mendapatkan cahaya penuh. Pada Gambar 6. bahwa perlakuan galur menunjukan tidak adanya perbedaan nyata. 


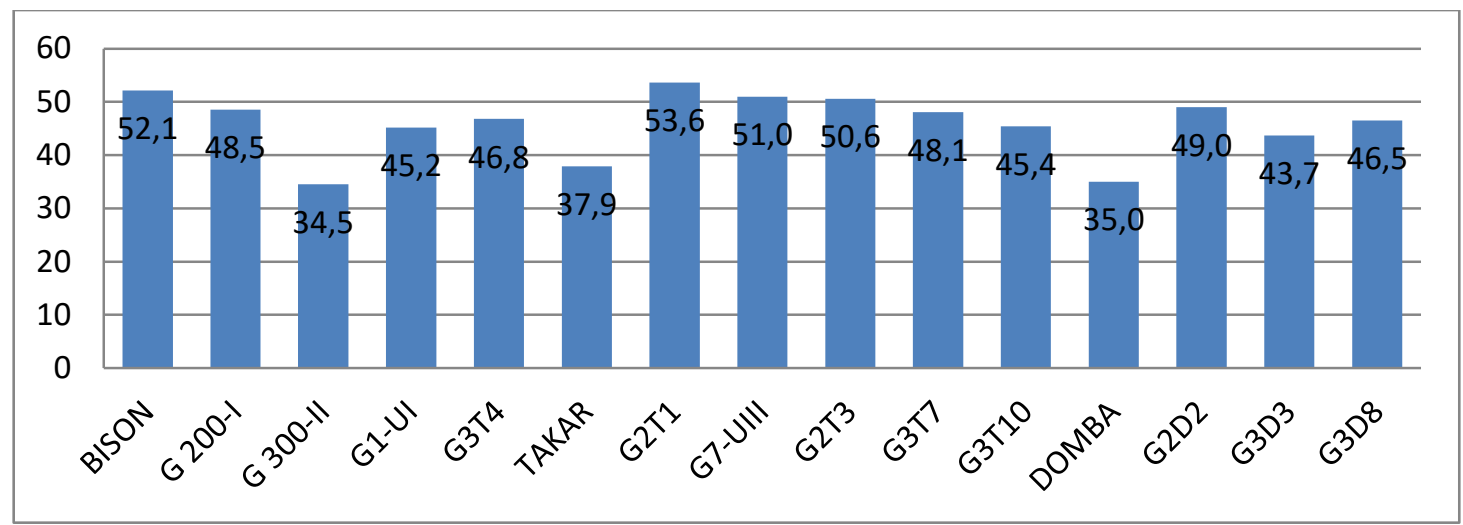

Gambar 6. Karakter Beberapa Galur pada Jumlah Daun (helai) Kacang Tanah terhadap Cekaman Naungan

Keterangan: Angka-angka yang diikuti oleh huruf yang sama pada titik umur tanaman yang sama menunjukan hasil yang tidak berbeda nyata pada uji DMRT taraf nyata 5\%; $\mathrm{n}_{0=}$ tanpa naungan, $\mathrm{n}_{1=}$ cekaman naungan

Tabel 2. Interaksi antara faktor naungan dengan galur pada jumlah cabang

\begin{tabular}{lrc}
\hline Galur & Tanpa Naungan $\left(\mathrm{n}_{0}\right)$ & Cekaman Naungan $\left(\mathrm{n}_{1}\right)$ \\
\hline BISON & $6,8 \mathrm{~b} \mathrm{~A}$ & $4,3 \mathrm{bc} \mathrm{B}$ \\
G 200-I & $7,3 \mathrm{bc} \mathrm{A}$ & $3,5 \mathrm{ab} \mathrm{B}$ \\
G 300-II & $6,2 \mathrm{~b} \mathrm{~A}$ & $3,5 \mathrm{ab} \mathrm{B}$ \\
G1-UI & $7,7 \mathrm{bc} \mathrm{A}$ & $3,3 \mathrm{ab} \mathrm{B}$ \\
G3T4 & $8,0 \mathrm{c} \mathrm{A}$ & $4,2 \mathrm{c} \mathrm{B}$ \\
TAKAR & $8,0 \mathrm{c} \mathrm{A}$ & $2,8 \mathrm{a} \mathrm{B}$ \\
G2T1 & $8,2 \mathrm{c} \mathrm{A}$ & $4,8 \mathrm{c} \mathrm{B}$ \\
G7-UIII & $9,0 \mathrm{~cd} \mathrm{~A}$ & $4,0 \mathrm{ab} \mathrm{B}$ \\
G2T3 & $8,8 \mathrm{~cd} \mathrm{~A}$ & $4,5 \mathrm{bc} \mathrm{B}$ \\
G3T7 & $7,8 \mathrm{bc} \mathrm{A}$ & $4,5 \mathrm{bc} \mathrm{B}$ \\
G3T10 & $7,2 \mathrm{bc} \mathrm{A}$ & $3,3 \mathrm{ab} \mathrm{B}$ \\
DOMBA & $4,3 \mathrm{a} \mathrm{A}$ & $3,7 \mathrm{bc} \mathrm{B}$ \\
G2D2 & $9,5 \mathrm{~d} \mathrm{~A}$ & $4,0 \mathrm{bc} \mathrm{B}$ \\
G3D3 & $8,3 \mathrm{~d} \mathrm{~A}$ & $3,2 \mathrm{ab} \mathrm{B}$ \\
G3D8 & $5,3 \mathrm{~b} \mathrm{~A}$ & $3,5 \mathrm{ab} \mathrm{B}$ \\
\hline K & & $\mathrm{c}$
\end{tabular}

Keterangan: Angka-angka yang diikuti oleh huruf kecil yang sama pada setiap kolom yang sama tidak berbeda nyata dan angka-angka yang diikuti oleh hurup kapital yang sama pada setiap baris yang sama tidak berbeda nyata pada uji DMRT taraf nyata $5 \%$

Berdasarkan Tabel 2. karakter jumlah cabang tanaman kacang tanah terlihat adanya interaksi diantara perlakuan naungan dan galur kacang tanah. Kombinasi antara perlakuan galur dengan perlakuan tanpa naungan menunjukan bahwa galur G2D2 memperoleh jumlah cabang yang lebih tinggi. Berarti galur tersebut lebih tahan apabila di tanam pada kondisi tanpa naungan. Sedangkan kombinasi antara perlakuan galur kacang tanah dengan perlakuan cekaman naungan menampilkan bahwa galur G2T1 menghasilkan jumlah cabang yang lebih tinggi. Berarti bahwa galur tersebut merupakan galur kacang tanah yang dapat di tanama pada kondisi cekaman naungan. Peningkatan jumlah cabang disebabkan karena intensitas cahaya yang tinggi dapat mempengaruhi proses fotosintesis juga meningkat. Hasil fotosintesis akan ditranslokasikan keseluruh jaringan tanaman melalui floem, yang selanjutnya energi hasil fotosintesis tersebut akan dipergunakan tanaman untuk mengaktifkan pertumbuhan tunas, daun, dan batang

Lifiani, R., Sutresna., I.W., dan Hemon, A.F. 
sehingga tanaman tumbuh lebih optimal. Namun, selain pengaruh cahaya peningakatan jumlah cabang kacang tanah juga dipengaruhi oleh faktor galur tersebut atau faktor genotip pada karakter sifat tanaman kacang tanah itu sendiri.

Tabel 3. Rerata saat awal berbunga dan jumlah bunga pada perlakuan naungan dan perlakuan beberapa galur kacang tanah

\begin{tabular}{|c|c|c|c|c|}
\hline Perlakuan & $\begin{array}{c}\text { Awal Berbunga } \\
\text { (hari) }\end{array}$ & Jumlah Bunga & $\begin{array}{l}\text { Luas daun } \\
\left(\mathrm{cm}^{2}\right)\end{array}$ & $\begin{array}{l}\text { Jumlah } \\
\text { trichoma }\end{array}$ \\
\hline \multicolumn{5}{|c|}{$\begin{array}{c}\text { Perlakuan } \\
\text { naungan }\end{array}$} \\
\hline Tanpa Naungan & $25,8 \mathrm{a}$ & $22,7 \mathrm{a}$ & $47,2 \mathrm{a}$ & 30,1 \\
\hline $\begin{array}{l}\text { Cekaman } \\
\text { Naungan }\end{array}$ & $33,5 \mathrm{~b}$ & $11,4 \mathrm{~b}$ & $31,1 \mathrm{~b}$ & 31,9 \\
\hline \multicolumn{5}{|c|}{ Perlakuan galur } \\
\hline BISON & 29,2 abcd & $22,5 \mathrm{~d}$ & 37,0 & 29,8 \\
\hline G 200-I & 30,7 bcde & $14,2 \mathrm{ab}$ & 44,1 & 29,9 \\
\hline G 300-II & $31,3 \mathrm{de}$ & $12,0 \mathrm{a}$ & 34,7 & 28,1 \\
\hline G1-UI & $28,5 \mathrm{ab}$ & $15,0 \mathrm{abc}$ & 38,4 & 27,9 \\
\hline G3T4 & $29,2 \mathrm{abcd}$ & 16,4 abc & 46,7 & 31,8 \\
\hline TAKAR & $31,7 \mathrm{e}$ & $15,8 \mathrm{abc}$ & 33,1 & 29,9 \\
\hline G2T1 & 29,2 abcd & $18,1 \mathrm{abcd}$ & 38,4 & 26,5 \\
\hline G7-UIII & $28,2 \mathrm{a}$ & $18,9 \mathrm{bcd}$ & 38,2 & 35,7 \\
\hline G2T3 & 29,7 abcde & $15,9 \mathrm{abc}$ & 40,4 & 34,9 \\
\hline G3T7 & 30,0 abcde & 17,8 abcd & 41,7 & 32,2 \\
\hline G3T10 & $28,8 \mathrm{abc}$ & $17,5 \mathrm{abcd}$ & 39,2 & 31,1 \\
\hline DOMBA & 29,8 abcde & $15,8 \mathrm{abc}$ & 39,0 & 33,9 \\
\hline G2D2 & $28,7 \mathrm{ab}$ & 17,7 abcd & 37,6 & 29,6 \\
\hline G3D3 & 31,0 cde & $20,7 \mathrm{~cd}$ & 40,5 & 32,8 \\
\hline G3D8 & 28,8 abc & 17,7 abcd & 38,9 & 32,3 \\
\hline
\end{tabular}

Keterangan: Angka-angka yang diikuti oleh huruf yang sama pada setiap perlakuan pada kolom yang sama tidak berbeda nyata pada uji DMRT taraf nyata 5\%

Pada Tabel 3. bahwa perlakuan naungan pada kacang tanah berbeda nyata terhadap semua parameter yaitu parameter awal berbungan, jumlah bunga, luas daun, dan jumlah kerapatan trichoma. Pada parameter awal berbunga diperoleh dari nilai rata-rata yang terendah. Perlakuan tanpa naungan berbunga lebih awal yaitu 25,8 hst dibandingkan perlakuan naungan 33,5 hst. Pada perlakuan beberapa galur bahwa G7-UIII lebih awal berbunga yaitu 28,2 hst. Pada jumlah bunga bahwa perlakuan tanpa naungan lebih banyak yaitu 22,7 dan perlakuan cekaman naungan sebanyak 11,4. Sedangkan berdasarkan pengaruh beberapa galur diperoleh jumlah bunga terbanyak yaitu pada galur BISON. Jumlah bunga pada perlakuan tanpa naungan lebih banyak diduga karena hasil fotosintesis yang optimal diperoleh tanaman tersebut. Selain itu, hasil asimilat yang diperoleh lebih banyak sehingga digunakan untuk pertumbuhan generatif dengan menghasilkan bunga yang lebih banyak. Menurut Taiz dan Zeiger (2002) bahwa tanaman yang tumbuh pada kondisi intensitas cahaya rendah akan mengalami fase vegetatif yang lebih lama. Bunga yang menyerbuk akan menjadi ginofor dan ginofor berwarna hijau dikarenakan butiran klorofil yang bisa berfotosintesis saat masih di atas tanah. Ginofor yang tumbuh dekat dengan tanah akan lebih cepat mencapai tanah dan lebih lama dalam pengisian polong. Luas daun tanaman kacang tanah menunjukan berbeda nyata bahwa perlakuan tanpa naungan lebih tinggi yaitu $47,2 \mathrm{~cm}^{2}$ dibandingkan cekaman naungan yaitu $31,1 \mathrm{~cm}^{2}$. Hasil luas daun tanaman kacang tanah yang

Lifiani, R., Sutresna., I.W., dan Hemon, A.F. 
diperoleh tersebut tidak sesuai dengan pendapat Djukri dan Poerwoko (2003) yang menyatakan bahwa peningkatan luas/lebar daun merupakan salah satu jenis adaptasi tanaman terhadap cekaman naungan (intensitas cahaya rendah) melalui pengefisienan energi cahaya matahari agar dapat berfotosintesis secara normal. Namun, luas daun pada kacang tanah yang dihasilkan sesuai dengan pernyataan Suryadi et al., (2013) meyatakan bahwa jumlah daun pada tanaman kacang tanah berhubungan erat dengan luas daun, sehingga semakin banyaknya jumlah daun yang terbentuk maka akan dihasilkan luas daun yang lebih tinggi pula. Luas daun yang diperoleh kacang tanah pada tanpa naungan lebih tinggi dikarenakan hasil fotosintesis yang diperoleh tanaman juga terbatas karena hasil fotosintesis yang diperoleh akan dibagikan keseluruh tubuh tumbuhan sehingga akibat hasil fotosintesis yang terbagi membuat daun tanaman berupaya untuk memperoleh cahaya yang lebih optimal dengan cara memperlebar luas daun. Berdasarkan faktor perlakuan galur kacang tanah bahwa tidak menunjukan adanya perbedaan nyata terhadap luas daun kacang tanah.

Berdasarkan nilai rerata pada jumlah kerapatan trichoma dengan bidang pandang $10 * 10$ diperoleh bahwa perlakuan naungan dan beberapa galur kacang tanah tidak berbeda nyata. Trichoma berfungsi untuk menghambat laju transpirasi, sehingga semakin banyak jumlah trikhoma pada permukaan daun dapat mencegah transpirasi yang berlebihan pada kondisi cekaman kering, sebaliknya stomata dalam jumlah sedikit akan akan mengurangi laju transpirasi. Menurut Salisbury dan Ross (1992) menyatakan bahwa salah satu adaptasi yang dapat menurunkan laju transpirasi adalah banyak jumlah bulu atau trichoma pada permukaan daun, sedangkan kerapatan stomata yang tinggi akan meningkatkan laju transpirasi daripada kerapatan stomata yang rendah.

Tabel 4. Rerata berat segar dan kering akar, rerata berat segar dan kering tanaman pada perlakuan naungan dan perlakuan beberapa galur kacang tanah

\begin{tabular}{lcccc}
\hline Perlakuan & $\begin{array}{c}\text { Berat Segar } \\
\text { Akar }(\mathrm{g})\end{array}$ & $\begin{array}{c}\text { Berat Kering Akar } \\
(\mathrm{g})\end{array}$ & $\begin{array}{c}\text { Berat Segar } \\
\text { Tanaman }(\mathrm{g})\end{array}$ & $\begin{array}{c}\text { Berat Kering } \\
\text { Tanaman }(\mathrm{g})\end{array}$ \\
\hline \multicolumn{5}{c}{$\begin{array}{c}\text { Perlakuan } \\
\text { naungan }\end{array}$} \\
\hline Tanpa Naungan & $2,1 \mathrm{a}$ & $0,8 \mathrm{a}$ & $61,9 \mathrm{a}$ & $18,0 \mathrm{a}$ \\
Cekaman Naungan & $0,6 \mathrm{~b}$ & $0,2 \mathrm{~b}$ & $22,1 \mathrm{~b}$ & $5,4 \mathrm{~b}$ \\
\hline \multicolumn{5}{c}{ Perlakuan Galur } \\
\hline BISON & 1,2 & 0,5 & $49,7 \mathrm{~b}$ & 12,9 \\
G 200-I & 1,5 & 0,7 & $53,7 \mathrm{~b}$ & 13,3 \\
G 300-II & 0,9 & 0,4 & $28,1 \mathrm{a}$ & 8,0 \\
G1-UI & 1,0 & 0,4 & $36,4 \mathrm{ab}$ & 10,4 \\
G3T4 & 1,6 & 0,6 & $48,6 \mathrm{~b}$ & 13,6 \\
TAKAR & 1,4 & 0,5 & $39,1 \mathrm{ab}$ & 11,2 \\
G2T1 & 1,6 & 0,5 & $51,4 \mathrm{~b}$ & 12,4 \\
G7-UIII & 1,4 & 0,5 & $43,6 \mathrm{ab}$ & 12,8 \\
G2T3 & 1,3 & 0,5 & $40,7 \mathrm{ab}$ & 10,8 \\
G3T7 & 1,6 & 0,6 & $41,6 \mathrm{ab}$ & 12,2 \\
G3T10 & 1,3 & 0,5 & $39,2 \mathrm{ab}$ & 12,5 \\
DOMBA & 1,8 & 0,7 & $46,9 \mathrm{~b}$ & 14,8 \\
G2D2 & 1,4 & 0,5 & $41,2 \mathrm{ab}$ & 10,9 \\
G3D3 & 1,2 & 0,4 & $43,6 \mathrm{ab}$ & 12,2 \\
G3D8 & 1,1 & 0,4 & $26,3 \mathrm{a}$ & 8,0 \\
\hline K2
\end{tabular}

Keterangan: Angka-angka yang diikuti oleh huruf yang sama pada setiap perlakuan pada kolom yang sama tidak berbeda nyata pada uji DMRT taraf nyata 5\%

Lifiani, R., Sutresna., I.W., dan Hemon, A.F. 
Berat segar tanaman merupakan komponen bahan yang dihasilkan selama pertumbuhan tanaman. Berdasarkan Tabel 4. bahwa pada perlakuan naungan menunjukan adanya perbedaan nyata antara tanpa naungan dengan cekaman naungan. Nilai rerata tertinggi terdapat pada perlakuan tanpa naungan sebesar 61,9 $\mathrm{g}$ dibandingkan perlakuan cekaman naungan sebesar 22,1 g. Sedangkan perlakuan galur berbeda nyata terhadap parameter berat segar tanamana dengan nilai rerata tertinggi yaitu galur G200-I sebesar 53,7 g. Menurut Gultom et al., (2015) bahwa semakin tinggi pengaruh naungan yang diberikan pada budidaya tanaman, maka biomassa yang dihasilkan akan menurun. Penurunan biomassa disebabkan karena jumlah daun yang dihasilkan tanaman ternaungi lebih sedikit dibandingkan tanpa naungan. Berdasarkan karakter morfologi sebelumnya bahwa jumlah daun dan jumlah cabang lebih besar terdapat pada tanpa naungan dibandingkan dengan ternaungi. Berat berangkasan kering tanaman kacang tanah pada perlakuan tanpa naungan dengan perlakuan cekaman naungan berbeda nyata. Nilai rerata berat kering tanpa naungan lebih besar yaitu 18,0 g, dibandingkan nilai rerata pada perlakuan cekaman naungan yaitu 5,4 g. Berat berangkasan kering tanaman berkaitan dengan dengan jumlah cabang, tinggi batang utama, jumlah daun dan akar tanaman kacang tanah. Zulyana (2011) menyebutkan, bobot kering tajuk tanaman akan meningkat jika fotosintesis meningkat, sehingga biomassa akan terserap seiring dengan berjalannya proses fotosintesis meningkat. Hal ini didukung oleh pendapat Suryadi et al., (2013) bahwa pada tanaman yang mendapat cahaya yang lebih banyak, maka intensitas cahaya yang diterima akan lebih tinggi sehingga proses fotosintesis akan berjalan lebih cepat, dan suplai karbohidrat akan bertambah sehingga bobot kering tanaman juga akan semakin bertambah.

Pada berat segar akar dan berat kering akar perlakuan naungan menunjukan adanya perberbedaan nyata. Pada karakter berat segar akar bahwa perlakuan tanpa naungan lebih tinggi sebesar 2,1 g dibandingkan perlakuan cekaman naungan 0,6 g. Berat kering akar perlakuan tanpa naungan $0,8 \mathrm{~g}$ dan cekaman naungan 0,2 g. Sedangkan berdasarkan perlakuan beberapa galur tidak menunjukkan adanya perbedaan nyata. Hasil penelitian ini sejalan dengan penelitian Alvarenga et al., (2004) yang mengatakan bahwa tanaman perlakuan tanpa naungan menghasilkan berat basah akar yang lebih tinggi dibandingkan dengan tanaman ternaungi. Berat kering akar pada cekaman naungan lebih rendah dibandingkan tanpa naungan karena pada kondisi ternaungi tanaman tidak memperoleh cahaya yang cukup dalam proses fotosintesis yang akan menghasilkan fotosintat yang lebih banyak, fotosintat yang lebih besar kemungkinan akan membentuk organ tanaman yang lebih besar pula kemudian menghasilkan produksi bahan kering yang semakin besar (Nasution et al., 2018).

Pembetukan polong kacang tanah merupakan karakter morfologi yang menentukan hasil produksi tanaman dari berbagai perkembangan dan pertumbuahan tanaman sejak awal vegetatif sampai pada pembungaan. Berdasarkan hasil yang diperoleh pada Tabel 4. menunjukan bahwa perlakuan cekaman naungan dengan tanpa naungan memberikan perberbedaan nyata. Nilai rerata berat segar polong tanpa naungan yaitu 18,2 g dan cekaman naungan $3,2 \mathrm{~g}$. Sedangkan berat kering polong yaitu 10,5 g pada perlakuan tanpa naungan dan naungan $1,5 \mathrm{~g}$. Berat polong berkaitan dengan jumlah polong yang diperoleh pada tanaman kacang tanah. Jumlah polong kacang tanah perlakuan tanpa naungan 7,8 dan perlakuan cekaman naungan 2,2, jumlah polong isi perlakuan tanpa naungan 6,7 dan perlakuan cekaman naungan 1,4, sedangkan jumlah polong cipo perlakuan tanpa naungan tidak berbeda nyata dengan perlakuan cekaman naungan. Dari berat polong, jumlah polong, dan jumlah polong isi menunjukkan adanya pengaruh nyata perlakuan naungan. Hal ini sesuai dengan pernyataan Rahmanda et al., (2017) 
menyatakan bahwa pada saat awal pembentukan polong dan pengisian polong tanaman kacang tanah pada umumya membutuhkan intensitas cahaya yang tinggi. Intensitas cahaya rendah pada awal pembentukan polong akan menyebabkan jumlah polong pertanaman dan jumlah biji yang terbentuk berkurang. Penanaman di bawah naungan $70 \%$ menunjukan penurunan yang cukup besar dibandingkan dengan tanaman yang ditanam di bawah sinar matahari penuh (Rezai et al., 2018).

Tanaman kacang tanah memiliki respon ketahanan terhadap naungan yang berbeda-beda, untuk mengetahui tolerannya suatu galur terhadap naungan dapat ditentukan dengan mengetahui nilai indeks sensitivitas cekaman naungan (S). Nilai sensitivitas dapat diperoleh dengan menghitung ratio hasil dari semua karakter morfologi, namun pada pengamatan tersebut ada 2 karakter yang dilihat tingkat toleransinya terhadap cekaman naungan. Parameter yang digunakan untuk mengetahui indeks sensitifitas cekaman naungan yaitu berat kering polong, dan jumlah polong isi. Menurut Hemon (2006) bahwa karakter utama yang perlu diperhatikan pada pengujian sifat toleransi kacang tanah terhadap kondisi tercekam kekeringan adalah berat kering polong dan jumlah polong.

Tabel 5. Rerata berat segar polong dan berat kering polong per tanaman pada perlakuan naungan dan perlakuan beberapa galur kacang tanah

\begin{tabular}{lcc}
\hline Perlakuan & Berat Segar Polong $(\mathrm{g})$ & Berat Kering Polong $(\mathrm{g})$ \\
\hline & Perlakuan Naungan \\
Tanpa Naungan & $18,2 \mathrm{a}$ & $10,5 \mathrm{a}$ \\
Cekaman Naungan & $3,2 \mathrm{~b}$ & $1,5 \mathrm{~b}$ \\
\hline \multicolumn{3}{c}{ Perlakuan Galur } \\
\hline BISON & 12,9 & 9,3 \\
G 200-I & 9,5 & 4,9 \\
G 300-II & 5,2 & 2,7 \\
G1-UI & 10,7 & 5,9 \\
G3T4 & 14,8 & 7,1 \\
TAKAR & 10,9 & 6,1 \\
G2T1 & 12,6 & 6,2 \\
G7-UIII & 11,0 & 6,7 \\
G2T3 & 10,0 & 5,3 \\
G3T7 & 12,3 & 6,6 \\
G3T10 & 11,2 & 6,2 \\
DOMBA & 8,8 & 4,4 \\
G2D2 & 10,7 & 5,8 \\
G3D3 & 10,2 & 7,1 \\
G3D8 & 9,7 & 5,4 \\
\hline
\end{tabular}

Keterangan: Angka-angka yang diikuti oleh huruf yang sama pada setiap perlakuan pada kolom yang sama tidak berbeda nyata pada uji DMRT taraf nyata $5 \%$.

Tabel 6. Rerata Jumlah Polong, jumlah polong isi, jumlah polong cipo pada perlakuan naungan dan perlakuan beberapa galur kacang tanah

\begin{tabular}{lccc}
\hline Perlakuan & JP & JPI & JPC \\
\hline & & Perlakuan Naungan \\
Tanpa Naungan & $7,8 \mathrm{a}$ & $6,7 \mathrm{a}$ & 0,5 \\
Cekaman Naungan & $2,2 \mathrm{~b}$ & $1,4 \mathrm{~b}$ & 0,3 \\
\hline & & Perlakuan Galur \\
\hline
\end{tabular}

Lifiani, R., Sutresna., I.W., dan Hemon, A.F. 


\begin{tabular}{lccc}
\hline Perlakuan & JP & JPI & JPC \\
\hline Tanpa Naungan & $7,8 \mathrm{a}$ & Perlakuan Naungan & 0,5 \\
Cekaman Naungan & $2,2 \mathrm{~b}$ & $6,7 \mathrm{a}$ & 0,3 \\
\hline & & $1,4 \mathrm{~b}$ & 0,5 \\
\hline BISON & 6,4 & Perlakuan Galur \\
G 200-I & 5,8 & 0,3 \\
G 300-II & 4,1 & 3,2 & 0,7 \\
G1-UI & 3,1 & 2,1 & 0,6 \\
G3T4 & 4,5 & 3,7 & 0,8 \\
TAKAR & 5,6 & 3,8 & 0,2 \\
G2T1 & 5,3 & 4,3 & 0,0 \\
G7-UIII & 5,1 & 5,4 & 0,2 \\
G2T3 & 6,2 & 3,5 & 0,3 \\
G3T7 & 4,3 & 4,8 & 0,6 \\
G3T10 & 5,4 & 4,8 & 0,6 \\
DOMBA & 5,8 & 3,1 & 0,3 \\
G2D2 & 3,8 & 3,8 & 0,3 \\
G3D3 & 5,0 & 4,1 & 0,9 \\
G3D8 & 5,7 & 3,7 & 0,3 \\
\hline
\end{tabular}

Keterangan: JP= Jumlah Polong; JPI= Jumlah Polong Isi; JPC= Jumlah Polong Cipo. Angka-angka yang diikuti oleh huruf yang sama pada setiap perlakuan pada kolom yang sama tidak berbeda nyata pada uji DMRT taraf nyata 5\%.

Tabel 7. Nilai Indeks Sensitivitas

\begin{tabular}{lccccc}
\hline & \multicolumn{5}{c}{ Nilai Sensitivitas (S) } \\
\hline Galur & BKP & JPI & Jumlah & Rerata & Fenotipe \\
\hline BISON & 0,96 & 0,87 & 1,83 & 0,89 & AT \\
G 200-I & 1,13 & 1,26 & 2,39 & 1,19 & P \\
G 300-II & 1,09 & 1,17 & 2,26 & 1,07 & P \\
G1-UI & 1,04 & 1,17 & 2,21 & 1,07 & P \\
G3T4 & 0,84 & 0,82 & 1,66 & 0,77 & AT \\
TAKAR & 1,08 & 1,10 & 2,18 & 1,07 & P \\
G2T1 & 0,97 & 0,74 & 1,71 & 0,85 & AT \\
G7-UIII & 1,05 & 1,11 & 2,16 & 1,07 & P \\
G2T3 & 1,10 & 1,12 & 2,22 & 1,12 & P \\
G3T7 & 0,95 & 0,97 & 1,92 & 0,95 & AT \\
G3T10 & 0,90 & 1,00 & 1,90 & 0,95 & AT \\
DOMBA & 0,74 & 0,56 & 1,30 & 0,59 & P \\
G2D2 & 1,03 & 1,11 & 2,14 & 1,07 & AT \\
G3D3 & 1,05 & 0,93 & 1,98 & 0,99 & AT \\
G3D8 & 0,84 & 0,84 & 1,68 & 0,84 & . \\
\hline
\end{tabular}

Keterangan: $\mathrm{S}=$ Nilai indeks sensitivitas; $\mathrm{T}=$ Toleran $(<0,5) ; \mathrm{AT}=\operatorname{Agak}$ Toleran $(0,5 \geq \mathrm{S} \leq$ 1); $\mathrm{P}=$ Peka ( $>1)$; $\mathrm{BKP}=$ Berat Kering Polong; JPI= Jumlah Polong Isi

Lifiani, R., Sutresna., I.W., dan Hemon, A.F. 
Berdasarkan nilai indeks sensitivitas cekaman naungan pada Tabel 7. menunjukan bahwa masing-masing galur memberikan respon yang berbeda terhadap perlakuan cekaman naungan. Dengan mengetahui tingkat sensitivitas tersebut maka penggolongan tanaman dapat ditentukan ke dalam toleran, agak toleran, atau peka. Berdasarkan 15 galur kacang tanah terdapat 8 galur yang memiliki indeks sensitivitas agak toleran terhadap perlakuan cekaman naungan yaitu G3T4, G2T1, G3T7, G3T10, Domba, G3D3, dan G3D8. Ada 7 galur yang memiliki indeks sensitivitas peka terhadap cekaman naungan yaitu G 200-I, G 300-I, G1-UI, TAKAR, G7U-III, G2-T3, dan G2D2. Keragaman fenotipe yang tampak merupakan hasil dari hubungan antara genotipe dan lingkungan (Murti et al., 2002). Setiap galur kacang tanah memberikan respon yang berbeda terhadap kondisi naungan. Kacang tanah yang peka akan mengalami penurunan produksi yang cukup tinggi, sedangkan kacang yang toleran mampu mempertahankan produksinya walaupun masih terjadi penurunan.

\section{KESIMPULAN}

Berdasarkan hasil analisis dan pembahasan dapat disimpulkan bahwa

1. Galur-galur kacang tanah menunjukan adanya interaksi secara nyata pada karakter morfologi jumlah cabang.

2. Karakter morfologi kacang tanah beberapa galur berbeda. Galur G3T7 menghasilkan tinggi tanaman lebih tinggi, galur BISON menghasilkan jumlah bunga yang lebih banyak. Galur G7-UIII menghasilkan lebih awal berbunga. Galur G3D8 menghasilkan berat segar tanaman lebih tinggi.

3. Cekaman naungan berpengaruh terhadap karakter morfologi tanaman kacang tanah kecuali jumlah kerapatan trichoma dan jumlah polong cipo.

4. Galur-galur kacang tanah yang memiliki sifat agak toleran terhadap cekaman naungan yaitu G3T4, G2T1, G3T7, G3T10, DOMBA, G3D3 dan G3D8.

5 .

\section{DAFTAR PUSTAKA}

Adisarwanto, T. (2000). Meningkatkan Produksi Kacang Tanah di Lahan Sawah dan Lahan Kering. Penebar Swadaya: Jakarta.

Anggraeni, B. W., Sopandie, D., \& Khumaida, N. (2010). Studi Morfo-Anatomi dan Pertumbuhan Kedelai (Glycine max (L) Merr.) pada Kondisi Cekaman Intensitas Cahaya Rendah. Skripsi. Departemen Agronomi dan Hortikultura. Fakultas Pertanian. Institut Pertanian Bogor. .

Ashari, S. (2006). Hortikultura Aspek Budidaya. UI-Press. Jakarta.

Gultom, E. N., Basyuni, M., Utomo, B. (2015). Pengaruh Intensitas Cahaya terhadap Pertumbuhan Konten Rantai Panjang Polyisoprenoid pada Mangrove Sejati Mayor Berjenis Sekresi (Sonneratia caseolaris L.). Peronema Forestry Science Jorunal 4(3): 173-179.

Handriawan, A., Weny, D. R., Tohari. (2016). Pengaruh Intensitas Naungan terhadap Pertumbuhan dan Hasil Tiga Kultivar Kedelai (Glycine maxL.) di Lahan Pasir Pantai Bugel, Kulon Progo. Vegetalika. 5(3): 1-14.

Hemon, A. F., Sumarjan., Hanafi. (2018). Perbaikan Karakter Tanaman Kacang Tanah: Toleran Naungan dan Berdaya Hasil Tinggi (>3,0 ton Polong Kering Per Hektar) Di Lahan Kering. Laporan Penelitian-Penelitian Terapan Unggul Perguruan Tinggi Unram. 
Ihsan, G. T., Arisanty, D., \& Normelani, E. (2021). Upaya petani meningkatkan produksi padi di Desa Tabihi Kecamatan Padang Batung Kabupaten Hulu Sungai Selatan. JPG (Jurnal Pendidikan Geografi), 3(2).

Maghfiroh, J. (2017). Pengaruh Intensitas Cahaya Terhadap Pertumbuhan Tanaman. Skripsi Jurusan Pendidikan Biologi, Fakultas MIPA, Universitas Negeri Yogyakarta.

Murti, R, H., Prajitno, D., Purwantoro, Tamrin, A. (2002). Keragaman genotip salak lokal Sleman. J. Habitat. 8(1): 57 - 63.

Nasution., Siti, A., Hanum, C., Ginting, J. (2018). Karakteristik Pertumbuhan Akar dan Tajuk Dua Varietas Lada Perdu (Piper nigrum L.) dengan Perlakuan Cekaman Naungan. Jurnal Pertanian Tropik. Vol 5 (1): 10-14.

Perrin, P. M., \& Mitchell, F. J. (2013). Effects of shade on growth, biomass allocation and leaf morphology in European yew (Taxus baccata L.). European Journal of Forest Research, 132(2), 211-218.

Rahmanda, R., Sumarni, T., Tyasmoro, S. Y. (2017). Respon Dua Varietas Kedelai (Glycine max. L) Terhadap Perbedaan Intensitas Cahaya Pada Sistem Agroforestry Berbasis Sengon. Jurnal Produksi Tanaman. 5 (9): 1561-1569.

Rais, S. A. (2004) Plasma Nutfah sebagai Sumber Gen untuk Menunjang Perbaikan Sifat dalam Perakitan Varietas Kacang Tanah. Buletin. AgroBiogen. 6 (2): 4857.

Rezai, S., Etemadi, N., Nikbakht, A., Yousefi, M., Majidi, M, M. (2018). Effect of Light Intensity on Leaf Morphology, Photosynthetic Capacity, and Chlorophyll Contentin Sage (Salvia officinalis L.). Horticultural Science and Technology. 36(1):46-57.

Salysbury, F, B., and Ross, C, W. (1992). Plant Physiology. Wadshwort Publishing Company. California.

Suprapto. (2008). Bertanam Kacang Tanah. Jakarta: Penebar Swadaya.

Suryadi., Setyobudi, L., Soelistyono, R. (2013). Kajian Intersepsi Cahaya Matahari pada Kacang Tanah (Arachis hypogaea L.) Diantara Tanaman Melinjo Menggunakan Jarak Tanam Berbeda. Jurnal Produksi Tanaman. 1(4): 333-341.

Taiz, L., and Zeiger, E. (2002). Plant Physiology. Third Edition. Sinauer Associate Inc. Publisher Sunderland, Massachusetts. 667 p.

Zulyana, U. (2011). Respon Ketimun (Cucumis sativus) terhadap Pemberian Kombinasi Dosis dan Macam Bentuk Pupuk Kotoran Sapi di Getasan. (Skripsi). Program Studi Agronomi, Fakultas Pertanian Universitas Sebelas Maret: Surakarta. 